\title{
Al-Qur'an And Radical Ideology; A Critical Study of "Al-Wa'ie" Tafsir by Rokhmat S. Labib
}

\author{
M.Taufiq Hidayat ${ }^{1}$, Yusuf Rahman ${ }^{2}$, Kusmana ${ }^{3}$, \\ \{taufiqalcik16@gmail.com¹, yusuf.rahman@uinjkt.ac.id², kusmana@uinjkt.ac.id ${ }^{3}$ \} \\ Graduate School of UIN Syarif Hidayatullah, Jakarta ${ }^{1}$, Ushuluddin Faculty of UIN Syarif Hidayatullah Jakarta ${ }^{2}$, \\ UIN Syarif Hidayatullah Jakarta ${ }^{3}$
}

\begin{abstract}
This article proves that the ideological construction of an interpretation determines the tendency of the product of interpretation and has the potential to reduce the meaning of a text and reject other interpretations. The findings in this article prove that the construction of the interpretation of Rokhmat S. Labib is more of a process of elaborating verses for certain interests by designing themes and sub-themes with tendentious conclusions and even blaming "infidel" Muslims who are not aligned, intolerant of differences, partial and fanatical. His interpretation is often separated from the context of the verse, which results in this work being inconsistent in taking references even though he does not ignore the historical context of the verse. This article also proves that the author's background determines the ideological tendencies and interests in an interpretation, more tendent an interpretation is more radical.
\end{abstract}

Keywords: Al-Wa'ie, Tafsir, Ideology, Radical

\section{Introduction}

Rokhmat S. Labib was a quite productive religious man. He has produced many works in the form of both written and video. He has a lot of ideas in his personal account such as; http://rokhmatslabib.blogspot.com,https://twitter.com/rokhmatlabib?lang=en,https://www.facebook.co m/ust.rokhmat.s.labib, and several yotube account channels; KhilafahChannel, NewsKhilafahChannel, and FokusKhilafahChannel.

Many of his ideas present religious matters both normatively and ideologically. In many of his writings he criticized and corrected the government. Among the narratives that are critical of the government is the failure to cultivate natural resources. In writing with the theme "Islamic Solutions Overcoming Adversity." He emphasized that the lives of most Indonesians are far from prosperous. Kriris not only hit the economic sector, but almost all sectors of life. He criticized the chaotic political conditions, the deteriorating education, corrupt morality, rampant crime and so on. Meanwhile, according to him, natural wealth is very abundant starting from the forest, various animals and fauna, the land, the beautiful nature. ${ }^{1}$ Nevertheless, he also provided solutions to the community with the theme "Prevent Disaster: Implement Sharia!". He interpreted the Koran Surat Saba [34]: 15-16. According to him the tragedy that happened was because they disobeyed His commands and turned away from His sharia, Allah also brought disaster to them. ${ }^{2}$

In the Beritagar.id media on Friday, 19 May 2017, a piece of news was displayed entitled "The Chairman of the DPP HTI Rokhmat S. Labib: The government has trampled on Pancasila." The content of the news is Labib's response to the issuance of Government Regulation in Lieu of Law (Perppu) Number 2 of 2017 concerning community organizations (Ormas) which then permanently dissolves the organization.. ${ }^{3}$

On another occasion, his writings on the caliphate in various media were very abundant. Among them Mediaoposition.com presents Labib's comments which were released on its website on March 18, 2018, giving the theme "KH. Rokhmat S. Labib: If the Khilafah Stands, They Will Not Easily Destroy Muslims ". The online radio site www.radiosilaturahim.com broadcasts news on the theme "HTI Comes to the People to Uphold the Islamic Caliphate". 5

Meanwhile, when asked about your intention to turn HTI into a political party? He answered that the definition of a political party is to foster society, care about people's affairs, not only about prayer and zakat, but also preaching how Muslims govern the country and society."6

Thus, Labib's writings are very abundantly uploaded in cyberspace, both in the form of his personal writings and interviews, seminars, news and videos that are spread on various sites and social media. In addition to completing his commentary work entitled "Tafsir Selected Verses of Al-Wai'ie", currently Labib is focusing on completing Tafsir Juz 30 and several letters in chapter 29 and several 
letters such as Surat Al-Furqan, Surat Muhammad, Surat Al- Hujurat also Surat Al-Fath which is in the process of editing. ${ }^{7}$

\section{Research methods}

In this paper the following methods are used; First, the perspective of the research data source is the type of library research study. This method is intended to trace written sources about a thought or phenomenon, in this case it is a product of the interpretation of Rokhmat S. Labib. This method is also used to explore the sources contained in the reference. Second, Interview, this method is intended for unilateral questions and answers which are carried out systematically and based on research objectives. Interviews were conducted directly with Rokhmat S. Labib to explore additional information about biographies, thoughts, and interpretations as well as to confirm data obtained from written sources. While the form of research in the analysis perspective is presented qualitatively to produce descriptive data. Thus, it can analyze the data obtained from literature reading and interviews and then produce descriptive data which is then analyzed to be proven and concluded. The data analysis method used is descriptive analytical, content analysis and comparative.

\section{Previous Research}

The academic community has not yet developed a detailed research framework for understanding the construction of ideological interpretations. Throughout this study, previous research studies have only described partial research on Labib's interpretation of one particular case, namely the question of the caliphate such as Farah Farida, his writing entitled Portrait of Ideological Interpretation in Indonesia; Study of the Interpretation of the Selected Verses of Al-Wa'ie. Farida concluded that the work was strongly influenced by the ideology of Hizb ut-Tahrir. Lufaefi in his two writings, Reconstruction of the Jargon of the Formalization of Sharia: Efforts to Maintain Unity in the Frame of Diversity and Criticism of the Interpretation of the Khilafah Verses: Study of Tafsir al-Wa'ie. According to him, this work is classified as a quasi objective, traditionalist revivalist style which does not touch the realm of the context at all.

Most studies have not captured the richness of Labib's interpretation in a comprehensive manner, even though he has many interpretations that have certain tendencies. Besides that, they did not elaborate with other interpreters. Some of them put this research into one discussion category and ignore other discussions. For this reason, research around Labib's interpretation is especially in the context of ideological interpretation whose object of study in this study emphasizes the study of radical ideology in the comprehensive interpretation of Rokhmat S Labib on all aspects of his interpretation which are not limited to his interpretive works but scattered writing in print and virtual media. Therefore, the object of study is not limited to the issue of the caliphate. This paper also assesses and verifies the authenticity and credibility of the sources it obtains and elaborates other interpretations as external criticism.

\section{Results and Discussion}

\subsection{Terminology of Ideology in Interpretation}

The definition of ideology in this paper refers to Nasr Hamid Abu Zayd's understanding of what he calls ideological interpretation. In his thinking, Abu Zayd sometimes uses the term ideology in a strict sense, namely as group awareness to protect their interests against other groups in a society. Sometimes he uses this term loosely when he criticizes any interpretation which in his view has no basis in the interpreted text itself. He also linked ideology with political and pragmatic manipulation of the meaning of texts, by contrasting ideology with scientific understanding. However, in general, Abu Zayd uses the word ideology to refer to religious interests, tendencies and beliefs. ${ }^{8}$

Ideology has an impact on the production of text so that it can construct the meaning of the subject, so that the right way to photograph the construction of ideology can be done through research on language. The Koran as a text is an open corpus that has the potential to accept all forms of exploitation, whether in the form of reading, translation, interpretation, and taking it as a source of reference. 9 


\subsection{Relationship between ideology and interpretation}

The sacred text of the guidelines for Muslim authority has the potential to be stretched out to be legitimized according to its justification. Ijtihad interpretation can be translated as part of the work of experts to understand reality in relation to the holy text of the Koran. The Ijtihad necessitates the occurrence of various interpretive opinions on the interpretation of the Qur'anic texts. In simple terms, the conception of ideology is an element of thought that is often used as a means of legitimating the truth or elements of belief which are used as the basis for belief and elements of action that are used as guidelines for human behavior. ${ }^{10}$

Therefore, in the view of critical discourse, all aspects of the text are empowered to wrap certain interests to be conveyed to readers or listeners. This is what lies behind the use of critical discourse as an analytical tool to reveal the forms and representations of ideology that occur in da'wah discourse texts produced by Hizbut Tahrir as organizations or religious groups that have certain ideologies. ${ }^{11}$ So that interpretations that are not in accordance with the context tend to be ahistorical or ideological. For example, when interpreting verses in the context of tawhid, then interpreted with the concept of Hakimiyyah. ${ }^{12}$

In short, ideological interpretation is an interpretation whose content contains an urgency of the interpreter's very tendentious subjectivity. The emergence of ideological bias has implications for the correctness of interpretation which is measured according to certain theological schools. As a result, the product of the interpretation at that time could not be separated from the interpreter's almameter, thus the political interpretation was power-oriented so that if there was a conflict, they would look for arguments to justify their opinion. ${ }^{13}$ Ideological reading of a text will produce authoritarianism and even radicalism in interpretation, this is because the approach used is ahistorical. ${ }^{14}$

\subsection{Radical Standardization in Interpretation.}

The radicalism to be translated in this paper refers to the opinion of Yusuf al-Qardawi in his work Al-Sahwah al-Islamiyyah: Baina al-Juhad wa al-Tatarruf so that it connotes an ideology that is unnatural or exaggerated as al-Qardawi calls it. ${ }^{15}$ It can be said that someone with a radical ideology is, first, intolerant of respecting the opinions of others. Second, fanatics who always feel right and think that others are wrong. Third, it tends to be exclusive or closed. Fourth, have revolutionary ideas that tend to be violent in achieving goals in their activities. ${ }^{16}$ This is confirmed by Adian Husaini's opinion. According to him, in socio-cultural and socio-religious terms, radical groups have strong group ties and display distinctive features of self-appearance and rituals. ${ }^{17}$

More specifically, according to the Majlis Ormas Islam (MOI), the characteristics of the radicalism movement are, firstly, rejecting the NKRI as the basic state of Pancasila and the 1945 Constitution. Second, being racist, imposing violence, killing and rebellion. Third, make efforts to weaken the resilience of the nation in the field of political ideology, economy, social culture and morals. Fourth, actively carry out disintegration. ${ }^{18}$ This criterion is strengthened by the state agency that has the authority in dealing with radicalism, namely the National Counterterrorism Agency (BNPT), which stipulates that at least four criteria can be considered radical. First, want to make changes quickly using violence in the name of religion; Second, takfîri or mengafakan other people; Third, support, spread, and invite to join the forbidden group. Fourth, interpret jihad in a limited manner. ${ }^{19}$ In addition, they made Islam the final ideology in regulating individual life and constitutional politics and rejected the Non-Middle Eastern ideology including Western ideology by using religious texts as a means of legitimacy or justification for their actions. Literal and partial or fragmentary understanding of the verses of the Koran and the Prophet's Hadith often results in a person trapped in narrow insights and unable to contextualize teachings with concrete life. ${ }^{20}$

\subsection{3 Labib's Ideological Interpretation of Reading}

\section{Interpretation of Tagut System}

Currently, the theme of the caliphate is familiar to Muslims in Indonesia. For Labib, who is an accomplished HTI fighter, the arguments relating to the caliphate are an inspiration for faith. Among other things, the interpretation of the caliphate in the Tafsir Al-Wai'ie is the 30th verse of the Qur'an Surah Al-Baqarah with the main title "The Position of Humans on Earth and the Obligation to Uphold the Khilafah" (Tafsir QS Al-Baqarah [2]: 30) ${ }^{21}$ Meanwhile, according to Labib, the opposite of the caliphate system is the tagut system. In the interpretation, it is explained about the meaning of tagut which is taken from the verse yuriduna an yatahakamuna ila tagut. ${ }^{22}$ Al-Asfahani interpreting the word tagut in language comes from the word taga which means tajawaz al-hadd al isyan, which is beyond the 
limit. Not much different, Labib interprets the word tagut in language with al-kathir al-tugyan, which is too much to go beyond the limit in iniquity. ${ }^{23}$

In fact, if you look at history when the verse above was revealed, it started from a personal case between a hypocrite and a Jew. To handle this case the Jews asked him to meet the Prophet Muhammad, but he refused and instead asked him to come back to the Ka'ab bin Al-Ashraf. This person is what Allah calls a tagut. This interpretation was agreed upon by al-Zamakhsyari. He explained that Allah nicknamed tagut because of his extreme actions against the Prophet or it could be because he was similar to Satan or because the choice to seek law from other than the Prophet was considered punishing Satan. ${ }^{24}$

The tagut word in the Koran is at least repeated in several letters including Surat Al-Baqarah [2]: 257, Surat Taha [20]: 24 and 43, Surat al-Nazi'at [79]: 17, Surat al-Alaq [ 96]: 6, Surat al-Kahf

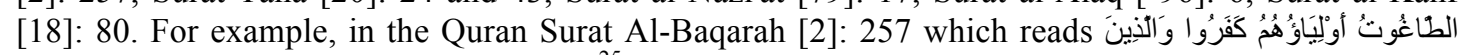
"And unbelievers, their leaders are tagut". ${ }^{25}$

Meanwhile Labib interprets these verses for people who are punished by laws other than sharia by the term Ansar tagut. According to him, it could be individuals or consist of several people or even an agency or institution or group that helps tagut or the tagut system. in this case helping can be done verbally, in writing or physically. Those affected by the treachery were infidels so that they were controlled by the Nationalists, Socialists, Democrats, and secularists. They ruled Indonesia with the law of ignorance and discarded the law of Allah, so they are tagut kafir who plunged the Muslim ummah into the darkness of life (shirk, munkar and disbelief) as explained in the Quran Surah Al-Baqarah: 257 above.

Meanwhile, Al-Tabari interpreted the word tagut in the 256th verse of Surat Al-Baqarah as Satan or a sorcerer. Al-Tabari did not associate it with the government system. ${ }^{26}$ Meanwhile in verse 257 tagut is a person who only believes in Prophet Isa but kufr in Prophet Muhammad. ${ }^{27}$

Labib's interpretation is closer to the meaning of tagut which is associated with political activities as Qutb interprets the meaning of the word tagut in the Qur'an, Surat al-Nisa, verse 51 above into the concept of God's sovereignty. In the interpretation of Qutb it is defined as aspects of government, politics and power, so that the interpretation tends to be ideological. ${ }^{28}$

Meanwhile, according to Lufaefi, the discourse of Islamization in a plural country as initiated by fundamentalists needs to be reviewed, namely through contextual ijtihad. The scope of the interpretation of the verses of the Koran must be expanded, through the study of text and context (quasi objectivist modernist). The jargon of Islamization should be reconstructed. The formalization of Islamic values can be done without having to dismantle existing laws. This is also in accordance with the objectives of Islamic law (al-maqashid al-shari'ah), which is to protect the rights of individuals as Indonesian citizens, who are not only Muslims. ${ }^{29}$ By implementing the traditions of mutual respect and protection, it is hoped that harmony in diversity will be maintained.

Makmun Rasyid divides the formulation of Islamic intent into two things; First, legal-formal Islam is Islam which only shows its symbolic side, without knowing how much Islamic values it contains. Second. True Islam is one that does not have to appear empirically through symbols, but implements substantial values in Islam, including respecting diversity and differences. ${ }^{30}$ The ideology of Pancasila is not an ideology that comes out of Islamic values, even in the core of each of its principles, namely divinity, humanity, unity, deliberation in achieving social justice for all people. ${ }^{31}$

The distinction between Labib and the interpreter whom he referred to is clear. Based on what has been described above, it can be concluded that Labib's interpretation is included in the category of interpretation with a tendency towards radical ideological reasoning. He interprets the meaning of tagut as related to the political aspect and tends to interpret it with a tagut stamp of leadership that does not have a caliphate system, even labib has the term Ansar tagut for groups who do not want to fight for or want to block and reject it. Its interpretation leads to nuances of intolerance to differences and tends to be literal in understanding the meaning of tagut.

Interpretation of Democracy.

The verse that approximates the word democracy in the Koran is "shura" recorded in the Koran Surah Ali Imran [3]: 159 and Surat Al-Shura [42]: 38. In his interpretation entitled "Shura is not democracy",32 Labib interprets the word of Allah: وامرهم شورى بينم "their business is being decided by deliberation between them."33

Labib emphasized that this verse is not a proof of democratic principles in a state. He interpreted that the shura in the Koran is not democracy. According to Labib, the highest sovereignty is not the people or the rulers but Islamic Sharia. They are all obliged to comply with the provisions, not the provisions of democracy. ${ }^{34}$ Meanwhile, democracy is a view of life and a system of government that makes the people as the holder of the highest sovereignty, which requires that all legislation be sourced 
from the people and its practical implementation is the parliament which is considered as the people's representation so as a consequence any laws that have been enacted by the parliament must be implemented and obeyed by the people; regardless of whether the law is in line with sharia or not. In the end Labib stated that all these principles were clearly vanity and contrary to Islam, contrary to the many propositions that obliged Muslims to apply sharia in the totality of life. ${ }^{35}$

In his interpretation he also refers to Taqiyuddin al-Nabahani that opinion taking (akhdh al-ra'y) is called shura if it is carried out by the caliph, amir, or the owner of authority, such as the chairman, commander, or person in charge of the person they lead. It can also be done between husband and wife when they want to wean their children before two years, they are ordered to discuss it. ${ }^{36}$

Perbedaan shura yang sangat mencolok dengan demokrasi - menurutnya- adalah dalam opinion taking. Shura in taking opinions is only done to Muslims, because damir hum (their pronoun) in this verse وامرهم شورى بينم refers to Muslims only. This shows that the same commandment is also conveyed in the words of Allah SWT: (Surah Ali Imran [3]: 159. Based on these two verses, Taqiyuddin al-Nabahani concludes that special shura is done on Muslims in a qath'i manner. with ibda 'al-ra'y who can be heard from everyone, both Muslim and non-Muslim. ${ }^{37}$

To strengthen his justification, Labib interprets wa al-ladhina [i] stajabu li rabbihim to show that they are people who welcome, accept and obey His sharia. Therefore, when they are praised for performing shura in all their affairs; then the shura they do is certainly in the corridor of sharia. Herein lies the importance of understanding the basis for decision making in shura. ${ }^{38}$

The globalmuslim.web.id site wrote a headline: "Inviting to Democracy is the same as Inviting to Jahannam". According to Labib, the parties that invite democracy are the parties that invite to the door of Jahannam !. Labib openly emphasized that democracy is a kufr system that follows the steps of the devil. "It is haram to take it, apply it and propagate it!"39

Labib's interpretation above confirms Abdul Qadim Zallum who claims that democracy is a kufr system that has been spread by the West to Islamic countries. He stated that this system was against Islamic laws. ${ }^{40}$ Thus a political system built on a democratic system is a tagut system and the actors of these systems can also be said to be the tagut.. ${ }^{41}$ Labib explained how bad democracy is, when attending the muzakaroh of figures and ulama organized by the Indonesian Young Ulama Intellectual Council (MIUMI) in Tebet Jakarta. He emphasized that due to the implementation of a democratic system, all laws that Allah sent down in the Koran must not be implemented before obtaining the approval of the DPR. ${ }^{42}$

Hizb ut-Tahrir rejects the modern state structure because it considers it a secular system and democracy is man-made which is not Islamic. ${ }^{43} \mathrm{He}$ has a view of total Islamization that must be implemented as a whole, regardless of democracy. He wants the democratic system to be abolished and to replace it with an Islamic legal system. ${ }^{44}$ In the provisions of Hizb ut-Tahrir deliberations as stipulated in Article 108 of the Muqaddimah al-Dustur: Opinions on an issue must pay attention to the following matters: First, there is no deliberation on issues relating to the determination of sharia law and syar'iyyah opinions. Second, taking opinions in matters relating to the definition of a case, both definitions that are syari'iyyah and non-syari'iyyah - for example, the definition of Sharia law. Third, in matters requiring expertise and knowledge, opinion taking must be referred to a person who is indeed an expert in this matter. Fourth, in matters relating to an activity to be carried out or technical matters, decision making is based on acclamation or a majority vote. ${ }^{45}$

On another occasion, Labib uploaded the theme "It's strange, why do oligarchs actually live in a democracy that protects the people's sovereignty?" Oligarchy is defined as political power held by a small elite group of society. Why does the democratic system in Indonesia live, such as the weakening of the KPK by some political elites. What is the difference with oligarchy in Islam? A group of people who are in power in Islam are still the implementers of sharia law, which they also run under the supervision of society whose interests are also the implementation of sharia law. ${ }^{46}$

Meanwhile, according to Al-Shawkani, this shura verse instructs one another without haste and not exclusively logically. Because it is said to be shura when conducting deliberations without prioritizing each other's logic. ${ }^{47}$ Ibn Kathir interprets this shura verse by telling the caliph Umar at the end of his life when he was stabbed and gathered his friends to choose who would replace him afterward. Shura which was done by Umar's best friend along with six other friends. ${ }^{48}$ While al-Zuhaili mentioned that Islamic law and religion is based on the doctrine of tawhid as a pure religious instrument and on justice and this is part of الديدمقر اطية solid democracy), there is no( سديدة) fanaticism in it, there is no injustice nor chaos and this way is the call of the Koran as a lamp. the whole world. ${ }^{49}$ This verse instructs them to exchange opinions and shura is a source of leadership. ${ }^{50}$ Thus the exegetes do not contradict democracy and shura. Al-Zuhaili even touched on democracy several times in its interpretation, for example in interpreting Surat al-Hujurat verse 13 of Al-Zuhaili. According to him, this ta'aruf verse is related to several things, including those related to equality. In 
terms of equality, all humans are the same, like comb teeth in human origin, they come from one father and the same mother and in rights and obligations and this is the principle of true democracy (aldimaqratiyyah al-haqqah). ${ }^{51}$

Meanwhile, the labib interpretation contradicts the two and even justifies democracy as a source of disbelief and immorality born from secularism, so calling for democracy is the same as inviting jahannam. There is a very significant difference between Labib's interpretation and the interpreters he refers to. He uses the text of religious authority to legitimize his ideological realm in forbidding democracy. This is an interpretive attitude that tends to have a radical tendency to disagree with groups who disagree by justifying democracy as a source of kufr and immorality born from secularism, which in turn upholds the democratic system or merely sympathizers means upholding the kufr system because everything invites kufr, even though in his statement was dissolved he stated to the Free People's Daily that HTI adhered to the existing laws, so this statement confuses his interpretation.

\section{Conclusion}

The product of interpretation is a manifestation of the author's ideological gesture, because it cannot be separated from the author's subjective ideas and ideas. Therefore, in an interpretation it is very important to first look at the background of the author. Such a reading will at least give birth to a picture or sketch and nuances of a certain tendency or even a strong interest in it.

The findings in this paper prove that the construction of Labib's interpretation is more of a process of elaborating verses for certain interests by designing tendentious themes and sub-themes full of radical ideology. In this case, the understanding and interpretation of the text of religious authority can be seen from the themes and sub-themes raised in the interpretation as well as the reflective conclusions of the verses it interprets with a radical ideological tendency. His interpretation which is often elaborated on is broader so that it is separated from the context of the verse even though he does not ignore the historical context of the verse. This paper also explains that the author's background determines the ideological tendencies in his interpretation and the construction of radical ideologies has the potential to reduce the meaning of religious texts and reject other interpretations, even blame, so that the more tendentious, the more radical. This paper shows a shift in the direction of interpretation from referring to the treasures of classical interpretation to the domain of ideological interests that is more dominant and results in this work being inconsistent in referring to classical works.

\section{References}

[1] Rokhmat S Labib "Islam Solusi Atasi Keterpurukan" "islam-solusi-atasi-keterpurukan", http://rokhmatslabib.blogspot.com/2007/07/islam-solusi-atasi-keterpurukan.html. Diakses hari selasa, 2 oktober 2018.

[2]Rokhmat S Labib, "Penguasa Berhati-hatilah", http://rokhmatslabib.blogspot.com/2007/07/penguasa-berhatihatilah.html. Diakses hari selasa, 2 oktober 2018.

[3] Heru Triyono, https://beritagar.id/artikel/berita/ketua-dpp-hti-rokhmat-s-labib-pemerintah-telah-injak-injakpancasila. Diakses hari selasa, 2 oktober 2018.

[4] Harian Rakyat Merdeka "Rokhmat S Labib: Banyak Parpol Yang Anggotanya Korupsi, Kenapa Organisasinya Tak Dipermasalahkan” https://www.rmol.co/read/2017/05/10/290884/Rokhmat-S-Lab0ib:-Banyak-ParpolYang-Anggotanya-Korupsi,-Kenapa-Organisasinya-Tak-Dipermasalahkan- diakses pada 02 September 2018.

[5] Radio silaturahim, "Rahmat S Labib HTI Hadir Di Tengah Umat Untuk Menegakkan Kekhilafahan Islam", http://www.radiosilaturahim.com/warta-rasil/rahmat-s-labib-hti-hadir-di-tengah-umat-untuk-menegakkankekhilafahan-islam/, diakses pada 2 oktober 2018.

[7] Heru Triyono "Ketua DPP HTI Rokhmat S. Labib: Jangan takut dengan gagasan negara Islam" dari https://beritagar.id/artikel/bincang/ketua-dpp-hti-rokhmat-s-labib-jangan-takut-dengan-gagasan-negara-islam, diakses 2 oktober 2018.

[8] Wawancara dengan Labib di Gedung DPP HTI yang beralamatkan Crown Palace Blok A 25 - 26, Jalan Prof. Soepomo No. 231, Tebet, RT.7/RW.1, Menteng Dalam, Kec. Tebet, Kota Jakarta Selatan, Daerah Khusus Ibukota Jakarta 12870. Pada hari Senin, 11 Februari 2019, 12:46:26 wib.

[9] Nasr Hamid Abu Zayd, Teks, Otoritas, Kebenaran. Penerjemah Sunarwoto, cet I, (Yogyakarta: LKiS, 2013), h. 161. Lihat Moch. Nur Ikhwan, Meretas Kesarjanaan Kritis Alquran, (Teraju: 2003), h. 87.

[9] M. Faisol Fatawi, Tafsir Sosiolingustik: Memahami Huruf Muqatha'ah dalam al-Qur'an, (Malang: UINMalang Press, 2009), h. 3.

[10] John B Thompson. Studies in the Theory of the Ideology, (University of California Press, 1984), h. 42. Konsep ideologi mungkin salah satu yang paling kompleks dari semua istilah, Dalam debat modern tentang ideologi terdapat paling tidak dua argumen utama. Pertama berpendapat bahwa ideologi sebagai teori palsu tentang kenyataan dapat diatasi dan digantikan oleh teori-teori ilmiah. Posisi lain mengasumsikan bahwa 
ideologi adalah sebuah momentum yang yang tak terhindarkan dari semua pemikiran dan tindakan. Lihat Ruth Wodak, "Language and Ideology: Language in Ideology" dalam Journal of Language and Politics 6:1, John Benjamins Publishing Company2007, h. 2.

[11] Budiman, "Ideologi Buletin Dakwah Al-Islam dalam Kajian Wacana Kritis”, jurnal Kuriositas, edisi VI, vol. 1, Juni 2013, h. 22.

[12] Ahlam Irfan, "Ahistorisitas Penafsiran dan Bias Ideologi Kajian Terhadap Konsep Kedaulatan Tuhan Menurut Sayyid Qutb” dalam Journal of Qur'an and Hadith Studies, vol. 3, no. 2 2014, h. 179.

[13] Abdul Mustaqim, Epistemologi Tafsir Kontemporer, (Yogyakarta: LKiS, 2010), h. 22.

[14] Irfan, "Ahistorisitas Penafsiran dan Bias Ideologi, h. 179.

[15] Al-Qardawi, Al-Sahwah al-Islamiyyah: ..., h. 23-29.

[16] Emna Laisa, "Islam dan Radikalisme", Islamuna Vol. 1 No. 1 (Juni 2014), h. 3.

[17] Adian Husaini, Hegemoni Kristen-Barat dalam Studi Islam di Perguruan

Tinggi (Jakarta: Gema Insani Press, 2006), h. 243.

[18] Ali Yusuf, Sikapi Radikalisme, MOI Sampaikan 4 Kriteria Radikal https://republika.co.id/berita/duniaislam/islam-nusantara/19/08/29/px02d1320-sikapi-radikalisme-moi-sampaikan-4-kriteria-radikal, diakses 2 oktober 2019.

[19] Aghnia Adzkia dan Sandy Indra, "Kriteria Situs Islam Radikal Versi BNPT", http://www.cnnindonesia.com/teknologi/20150401093434-185-43429/kriteria-situs-islam-radikal-versi-bnpt, diakses 21 Agustus 2020.

[20] Hasani Ahmad Said "Radikalisme Agama" Al- 'Adalah Vol. XII, No. 3, Juni 2015, h. 598

[21] Rokhmat S. Labib, Tafsir ayat pilihan al-Wa'ie, h. 75.

[22] Rokhmat S. Labib, Tafsir ayat pilihan al-Wa'ie, h.535.

[23] Rokhmat S. Labib, Tafsir ayat pilihan al-Wa'ie, h.539

[24] Al-Zamakhsyari, Tafsir Al-Kasyaf, vol.2, h.97.

[25] https://web.telegram.org/\#/im?p=@cinta_khilafah24. Diakses 29 Oktober 2019

[26] Al-T abari, Jami' Al-Bayan, vol. 5, h. 417.

[27] Al-T \{abari, Jami 'Al-Bayan, vol. 5, h. 425.

[28] Ahlam Irfani, "Ahistorisitas Penafsiran dan Bias Ideologi, (Kajian Terhadap Konsep Kedaulatan Tuhan Menurut Sayyid Qutb” dalam Journal of Qur'an and Hadith Studies, vol. 3, no. 2, 2014, h. 188.

[29] Lufaefi, "Rekonstruksi Jargon Formalisasi Syariat: Upaya Menjaga Persatuan dalam Bingkai Keberagaman", Jurnal Al-A'raf, vol. XIV, no. 1, Januari - Juni 2017, h. 86.

[30] Makmun Rasyid, HTI Gagal Paham Khilafah, (Ciputat: Compass, 2016), h. 8.

[31] Mujamil Qomar, Fajar Baru Islam Indonesia, (Bandung: Mizan, 2012), h. 8

[32] Rokhmat S Labib, Tafsir ayat pilihan al-Wa'ie, h. 589 dan 532.

[33] Rokhmat S Labib, Tafsir ayat pilihan al-Wa'ie, h. 593.

[34] Khilafah Channel, "Antara Iman dan Sistem Pemerintahan", diakses pada 22 Oktober 2019 dari https://www.youtube.com/watch?v=RcOL_5feX4g\&list=PL_SEZZOhjO1a5bYP9r5vPInplUC1Spf$\mathrm{f} \&$ index $=15$.

[35] Rokhmat S Labib, Tafsir ayat pilihan al-Wa'ie, h. 595-596.

[36] Rokhmat S Labib, Tafsir ayat pilihan al-Wa'ie, h. 593.

[37] Rokhmat S Labib, Tafsir ayat pilihan al-Wa'ie, h. 594.

[38] Rokhmat S Labib, Tafsir ayat pilihan al-Wa'ie, h. 595.

[39] Rokhmat S Labib, https://www.globalmuslim.web.id/2013/02/rokhmat-s-labib-mengajak-pada.html?m=0, diakses pada 2 oktober 2018.

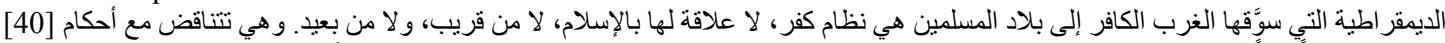

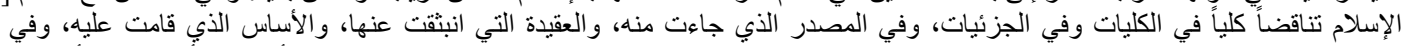
الأفكار والأنظمة التي أنت بها dalam bahasa Indonesia dengan judul Demokrasi Sistem Kufur : Haram Mengambilnya, Menerapkannya, dan Mempropagandakannya, (Bogor : Pustaka Thariqul Izzah, 1994, cet I).

[41] Abdul Qadim Zallum, Al-Dimuqratiyah Nizam Kufr, (tp:tt), h. 1.

[42] Arrahmah, "Miumi Ustadz Rokhmat Labib Utarakan Demokrasi Biang Kekufuran", https:/www.arrahmah.com/2013/10/11/miumi-ustadz-rokhmat-labib-utarakan-demokrasi-biang-kekufuran/, diakses pada 2 oktober 2018.

[43] Frank Schneider, "Hizb Ut-Tahrir: A Threat Behind A Legal Façade?”, (Tulisan, Naval Postgraduate School Monterey, California: June 2006), h. 8.

[44] Lufaefi, Rekonstruksi Jargon Formalisasi Syariah, h. 76, lihat Taqiyuddin An-Nabhani, Nizham Al-Hukm, (Beirut: Hizbut Tahrir, 2002), h. 131.

[45] Ketentuan Bermusyawarah; Pasal 108 Kitab Muqaddimah al-Dustur oleh Media Al-Wa'ie https://alwaie.id/telaah-kitab/ketentuan-bermusyawarah-pasal-108-kitab-muqaddimah-ad-dustur/. Diakses 01 November 2019.

[46] Rokhmat.S.Labib, “Aneh, kenapa oligarki justru hidup di demokrasi yang menjaga kedaulatan rakyat?”, diunggah pada 24 Oktober 2019, pukul 09.05, diakses pada 1 November 2019 dari https://www.facebook.com/ust.rokhmat.s.labib/.

[47] Al-Shawkani, Fath al-Qadir, (Da<r al-Wafa: Mabhath al-Tahkik wa al-Bahth al-'ilmiy,tt), h. 707-708.

[48] Ibn Kathir, Tafsir al-Qur'an al-Ad\{im, (Dar al-Kutub al-'Ilmiyyah: Beirut:tt), vol. 7, 211. 
[49] Wahbah bin Mustafa Al-Zuhaili, Al-Tafsi>r al-Muni>r fi al-'Aqi>dah wa alSyari >ah wa al-Manhaj (Damaskus:da $>$ r al-fikr 2003) vol. 9, h. 160.

[50] Fakhruddin Al-Razi, Al-Tafsir al-Kabir wa Mafatih al-Ghayb, (Beirut: Dar Ihya Turats al islami), vol. 27, h. 63.

[51] Wahbah bin Mustafa Al-Zuhaili, Al-Tafsi>r al-Muni>r fi al-'Aqi>dah wa alSyari>'ah wa al-Manhaj (Damaskus:da>r al-fikr 2003), vol.13, h. 596. 